NOTE

\title{
Temperature-dependency of Betanodavirus infection in SSN-1 cell line
}

\author{
S. Ciulli ${ }^{1, *}$, D. Gallardi ${ }^{1}$, A. Scagliarini ${ }^{1}$, M. Battilani ${ }^{1}$, R. P. Hedrick ${ }^{2}$, S. Prosperi ${ }^{1}$ \\ ${ }^{1}$ Department of Veterinary Public Health and Animal Pathology, Alma Mater Studiorum, University of Bologna, \\ Via Tolara di Sopra, 50, 40064 Ozzano Emilia (BO), Italy \\ ${ }^{2}$ Department of Medicine and Epidemiology, School of Veterinary Medicine, University of California, One Shields Avenue, \\ Davis, California 95616-8737, USA
}

\begin{abstract}
This study examined the in vitro effects of temperature on Betanodavirus infection in the SSN-1 cell line. A Betanodavirus isolated from moribund sea bass fry Dicentrarchus labrax farmed in the Adriatic Sea and characterised as a RGNNV (Redspotted Grouper Nervous Necrosis Virus) genotype was used. Virus-infected SSN-1 cells were incubated at temperatures between 10 and $30^{\circ} \mathrm{C}$ and observed for cytopathic effects daily for $15 \mathrm{~d}$. Cell-free and cell-associated viral growth were evaluated by $50 \%$ tissue culture infectious dose ( TCID $_{50}$ ) titration at $0,24,48,72,96$, $144,192,240,312$ and $360 \mathrm{~h}$ post-infection. Virus replication was observed at all temperatures from 15 to $30^{\circ} \mathrm{C}$. The optimal temperature for virus growth was $25^{\circ} \mathrm{C}$. A temperature of $10^{\circ} \mathrm{C}$ was detrimental to the growth of the SSN-1 cells and cell death interfered with interpretations of viral growth. The isolate of Betanodavirus from Italian sea bass in this study demonstrates a different temperature range for growth compared to previous reports for related Betanodavirus strains, most likely due to an adaptation to the normal environmental temperatures of the host fish species of origin.
\end{abstract}

KEY WORDS: Betanodavirus - Nervous necrosis virus · Viral encephalopathy and retinopathy · Dicentrarchus labrax $\cdot \mathrm{SSN}-1$ cell line $\cdot$ Temperature dependency $\cdot$ Viral growth

Resale or republication not permitted without written consent of the publisher

\section{INTRODUCTION}

Viral encephalopathy and retinopathy (VER) virus, otherwise known as viral nervous necrosis virus, is responsible for frequent outbreaks characterized by high mortality among a wide variety of marine fish species (Munday et al. 2002). The disease VER mainly affects the larval and juvenile stages, which show neurological symptoms due to the typical vacuolation and degeneration in the brain, spinal cord and retina (Munday et al. 2002). The disease is caused by a nonenveloped bi-segmented single-strand positive-sense RNA virus about 25 to $30 \mathrm{~nm}$ in diameter that has been classified in the family Nodaviridae, genus Betanodavirus (Ball et al. 2000). Based upon capsid protein gene sequences, members of the Betanodavirus can be separated into 4 genotypes: Striped Jack Nervous Necrosis Virus (SJNNV), Tiger Puffer Nervous Necrosis
Virus (TPNNV), Barfin Flounder Nervous Necrosis Virus (BFNNV) and Redspotted Grouper Nervous Necrosis Virus (RGNNV) (Nishizawa et al. 1997).

The observation of natural outbreaks and experimental infection show that water temperature plays an important role in the induction of the disease (Fukuda et al. 1996, Le Breton et al. 1997, Tanaka et al. 1998) and in vitro studies in cell lines confirm its important role in viral replication (Chi et al. 1999, Iwamoto et al. 2000, Lai et al. 2001, Aranguren et al. 2002). Differences in virus proliferation, cytopathic effect (CPE) and incubation temperatures were observed among viruses in each of the 4 genotypes by Iwamoto et al. (1999). Their studies demonstrated that RGNNV strains grew well at $25^{\circ} \mathrm{C}$ compared to $20^{\circ} \mathrm{C}$ for strains from the tiger puffer or barfin flounder tested. Subsequent studies by Ciulli et al. (2004) showed that temperature tolerances may also occur among strains of the RGNNV genotype. In 
order to further investigate these potential differences, we examined the viral growth characteristics of a particular strain of the RGNNV genotype as isolated from marine fish from Italy.

\section{MATERIALS AND METHODS}

Virus strain. The virus used in this study was isolated from naturally nodavirus-infected European sea bass fry Dicentrarchus labrax (3 mo of age) during an outbreak of VER when water temperature was ca. $25^{\circ} \mathrm{C}$ in the Adriatic Sea in Italy. RT-PCR with primers F2-R3 (Nishizawa et al. 1994) was conducted on viral RNA extract from the brain. The virus was isolated on SSN-1 cell line as previously described (Frerichs et al. 1996) and it was designated It/351/Sb.

The virus was further characterized following extraction of genomic RNA by the phenol:chloroform method (Chomczynski \& Sacchi 1987). Based upon known Betanodavirus sequences available from GenBank, primers S6 (5'-ATGGTACGCAAAGGTGATAA GAAA-3') and S7 (5'-GTT TTCCGAGTCAACACGGG T-3') were chosen to amplify the coding region of RNA2.

The PCR product was then purified using a High Pure PCR Product Purification Kit (Roche) and then sequenced in both directions with an automatic sequencer ABI 377 (Applied Biosystems). The sequences obtained were aligned and compared to those of the different genotypes available in GenBank (D30814: SJNNV; D38637: TPNNV; D38635: BFNNV; AHNVA: J245641; D38636: RGNNV) using Clustal W (Thompson et al. 1994) of Lasergene Biocomputing software (DNASTAR). The USA/1565/An strain isolated from white sea bass Atractoscion nobilis cultured in southern California used for previous temperature-dependency studies (Ciulli et al. 2004) was also included in the alignment.

Effect of temperature on Betanodavirus infection. SSN-1 cells were grown as monolayers in 12-well plates and then each well was inoculated with $10^{5.16}$ TCID $_{50}$ of It/351/Sb virus. Monolayers were washed twice with L-15 medium after $1 \mathrm{~h}$ incubation. Replicate plates were incubated at $10,15,20,25$ and $30^{\circ} \mathrm{C}$ and observed daily for the presence of CPE. At 0, 24, 48, 72, $96,144,192,240,312$ and 360 h post-infection, 2 wells of infected cells at each temperature were examined for the presence of both cell-free and cell-associated virus by titration on SSN-1 cells.

Virus titration. Cell culture medium and cells were collected by scraping the bottom of the wells and were then separated by centrifugation. Virus was released from cells by 2 cycles of freezing and thawing. The titrations were performed in 96 -well plates incubated at $25^{\circ} \mathrm{C}$. After $15 \mathrm{~d}$, the $50 \%$ tissue culture infectious dose $\left(\mathrm{TCID}_{50} \mathrm{ml}^{-1}\right.$ ) was calculated using the method of Reed \& Muench (1938).
Statistical analysis. All results obtained were expressed as means $\pm \mathrm{SD}$. Data were tested for significance by analysis of variance (ANOVA), followed by Tukey tests (Prism v4.0, GraphPad Software) to determinate differences among the obtained virus concentrations. Mean values were considered significant when $\mathrm{p}<0.05$.

\section{RESULTS}

\section{Virus isolation, RT-PCR and RNA2 characterization}

Viral RNA extracted from infected cell culture supernatant was amplified with the S6-S7 primers providing a specific $1014 \mathrm{bp}$ PCR product and a sequence of $987 \mathrm{bp}$ from the RNA2 segment of the It/351/Sb genome (GenBank accession number: AY620367).

The alignment obtained placed both the Italian isolate and the USA/1565/An strain (GenBank accession number: AY620368) into the RGNNV genotype. The It/351/Sb and USA/1565/An strains shared a 95.9\% sequence identity and similarities of 99.3 and $96.0 \%$, respectively, with the RGNNV reference strain, whereas sequence identity was less than $83.3 \%$ compared with other genotypes.

\section{Effect of temperature on It/351/Sb infection in SNN-1 cells}

CPE observed at 20, 25 and $30^{\circ} \mathrm{C}$ (Fig. 1B,G) at different time points consisted of the presence of typical cytoplasmatic vacuoles. The vacuolating process appeared $2 \mathrm{~d}$ post-infection at 30 and $25^{\circ} \mathrm{C}$, and at $4 \mathrm{~d}$ post-infection at $20^{\circ} \mathrm{C}$. At 20 and $25^{\circ} \mathrm{C}$, the complete disintegration of the monolayers occurred $4 \mathrm{~d}$ after the first appearance of CPE. On Day 5 after infection, CPE at $30^{\circ} \mathrm{C}$ began to decrease and disappeared by $9 \mathrm{~d}$ post-infection with cell re-growth leaving characteristic round aggregates of cells (Fig. $1 \mathrm{H}$ ). At $15^{\circ} \mathrm{C}$ and beginning on Day 4 post-infection, alterations to the monolayer but not the typical cytoplasmatic vacuoles were present in both infected and control SSN-1 cells. The cell began to detach and clustered, leading to a complete destruction of the monolayer (Fig. 1C,D) by Day 13. At $10^{\circ} \mathrm{C}$, both control and virus-inoculated cells began rounding by Day 4 and by Day 10 had detached and were floating in the medium (Fig. 1E,F).

\section{Virus titration}

Concentrations of cell-free and cell-associated virus were $10^{1.96 \pm 0.34}$ and $10^{4.24 \pm 0.56} \mathrm{TCID}_{50} \mathrm{ml}^{-1}$, respectively, immediately after adsorption of virus. Virus 

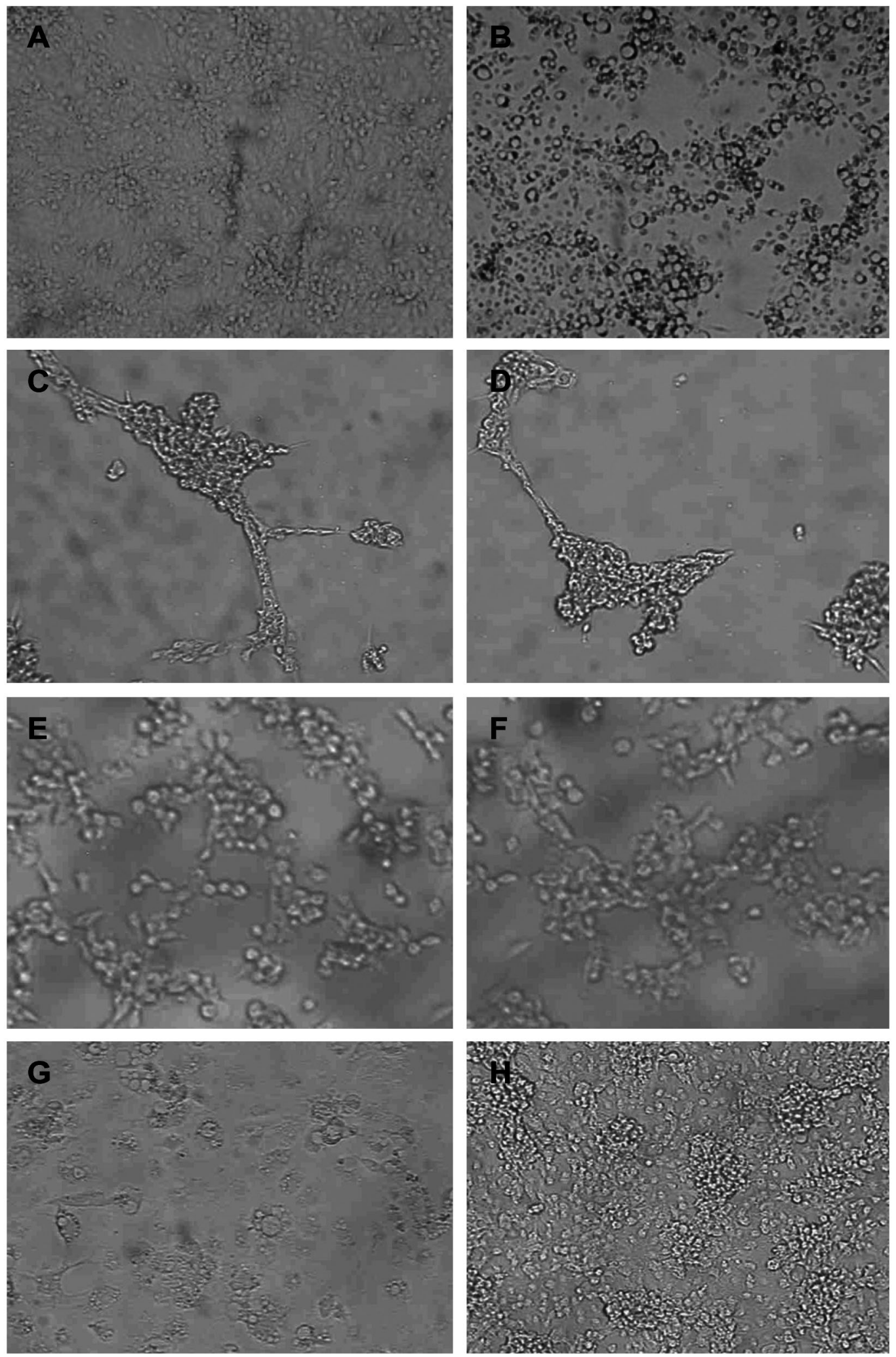

Fig. 1. Morphology of SSN-1 cells uninfected and infected. (A) Uninfected SSN-1 monolayer. (B) SSN-1 with typical vacuolation as observed at 20 and $25^{\circ} \mathrm{C}$. (C) SSN- 1 at $15^{\circ} \mathrm{C} 13 \mathrm{~d}$ post-infection with It/351/Sb. (D) SSN-1 at $15^{\circ} \mathrm{C} 13 \mathrm{~d}$ post-infection with mock inoculum. (E) SSN-1 at $10^{\circ} \mathrm{C} 10 \mathrm{~d}$ post-infection with It/351/Sb. (F) SSN-1 at $10^{\circ} \mathrm{C} 10 \mathrm{~d}$ post-infection with mock inoculum. (G) Infected SSN-1 at $30^{\circ} \mathrm{C} 9 \mathrm{~d}$ post-infection. (H) Infected SSN-1 at $30^{\circ} \mathrm{C} 13 \mathrm{~d}$ post-infection 
concentrations were greatest $(p<0.05)$ in the cell pellet, apparently due to a rapid and efficient adsorption of the virus to the cells.

In cell samples incubated at 20,25 and $30^{\circ} \mathrm{C}$ the virus concentrations increased markedly over time to provide typical growth curves but with significantly different optima reached at different time points (Fig. 2A).

At $30^{\circ} \mathrm{C}$, virus concentrations increased more rapidly but the maximum titres of cell-associated virus were reached at $72 \mathrm{~h}$ post-infection $(6.37 \pm 0.25)$, which was significantly less than the maximum titre obtained in cell-associated virus at $20^{\circ} \mathrm{C}$ at $240 \mathrm{~h}$ post-infection (7.93; $\mathrm{p}<0.05)$, and at $25^{\circ} \mathrm{C}$ at $144 \mathrm{~h}$ post-infection $(7.96 \pm 0.17$; $\mathrm{p}<0.05)$. Despite the lower concentrations of cell-associated virus at $30^{\circ} \mathrm{C}$, cell-free virus concentrations at this temperature appeared to be greater than those obtained at 20 and $25^{\circ} \mathrm{C}$ during the first $8 \mathrm{~d}$ following infection, but not significantly so ( $p>0.05$; Fig. $2 \mathrm{~B}$ ). Concentrations greater than $10^{7.5}$ were reached $8 \mathrm{~d}$ after infection at $25^{\circ} \mathrm{C}$ and at $10 \mathrm{~d}$ at $20^{\circ} \mathrm{C}$, a value similar to that observed at Day 3 at $30^{\circ} \mathrm{C}$. At $30^{\circ} \mathrm{C}$, virus concentrations began to decrease quickly after $10 \mathrm{~d}$ and by $13 \mathrm{~d}$ were significantly less than those at 20 or $25^{\circ} \mathrm{C}(\mathrm{p}<0.05$; Fig. 2B).

At $15^{\circ} \mathrm{C}$, viral growth was preceded by a long latent period. Significant increases in cell-associated virus concentrations from those at time 0 were not observed until $10 \mathrm{~d}$ post-infection $(\mathrm{p}<0.05)$. Maximum virus concentrations of $10^{6.13} \mathrm{TCID}_{50} \mathrm{ml}^{-1}$ in the cell-associated and $10^{6.17 \pm 0.38} \mathrm{TCID}_{50} \mathrm{ml}^{-1}$ in the cell-free samples were reached by $13 \mathrm{~d}$ post-infection (Fig. 2C).

Virus titres remained constant for all days tested for cell-associated samples incubated at $10^{\circ} \mathrm{C}$ with a slight increase in cell-free virus at $96 \mathrm{~h}$ post-infection (Fig. 2D).

\section{DISCUSSION}

This study examined the effects of temperature on the in vitro replication of an Italian Betanodavirus strain in the SSN-1 cell line. Outbreaks due to nodavirus among marine fish in Italy are usually observed in the summer when water temperatures are greater than $25^{\circ} \mathrm{C}_{i}$ however, some authors have described Betanodavirus outbreaks at temperatures as low as 14 to $15^{\circ} \mathrm{C}$ (Galeotti et al. 1999).

Our in vitro studies show that the It/351/Sb strain from Italy can grow at a wide range of temperatures (from 15 to $30^{\circ} \mathrm{C}$ with an optimum of $25^{\circ} \mathrm{C}$ ), which is similar to the range of permissive temperature for other strains of RGNNV tested. However, some grouper strains have been shown to have temperature optima of $28^{\circ} \mathrm{C}$ (Lai et al. 2001) and they may not be able to growth at $15^{\circ} \mathrm{C}$ (Iwamoto et al. 2000). In contrast, the USA/1565/An strain isolated from white sea bass (Curtis et al. 2001) was unable to grow at $30^{\circ} \mathrm{C}$ (Ciulli et al. 2004). As these fish species are farmed at different water temperatures, variations in growth temperatures for viruses within the same genoytpe
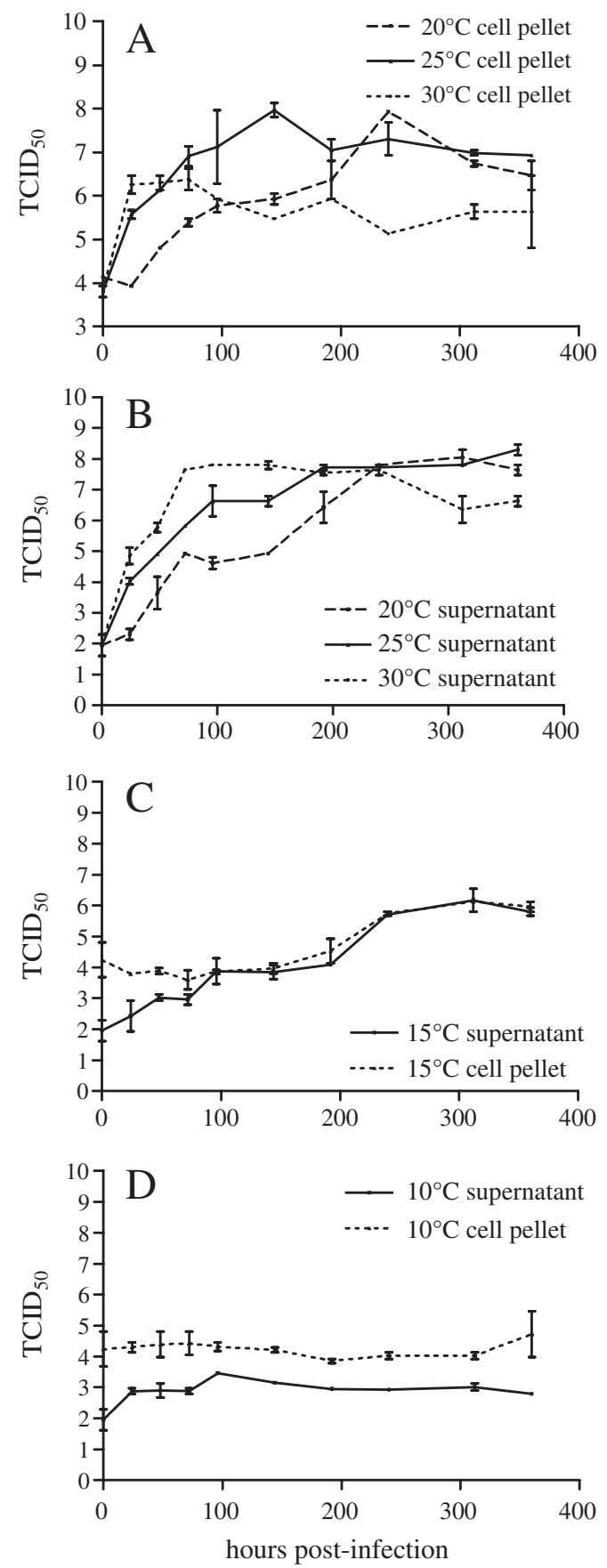

Fig. 2. Concentrations of cell-associated virus and cell-free virus in the supernatant observed at selected time points following inoculation of SSN-1 cells incubated at different temperatures. Error bars are $\pm \mathrm{SD}$. (A) Cell-associated virus at 20,25 and $30^{\circ} \mathrm{C}$. (B) Cell-free virus in the supernatant at 20,25 and $30^{\circ} \mathrm{C}$. Viral growth curves of virus at (C) $15^{\circ} \mathrm{C}$ and (D) $10^{\circ} \mathrm{C}$ 
may have adapted to the specific environments, as has been hypothesized for viruses of different genotypes (Iwamoto et al. 1999). The lack of correlation between growth temperature and genotype could be due to the fact that genotype classification is based on sequences of the RNA2 genome segment that encodes for virus coat protein (Nishizawa et al. 1997), while growth temperature differences would be more suitable to reflect differences in RNA1 segment that encodes for the RNA-polymerase (Mizumoto et al. 2002, Shuichi et al. 2003).

The observation of viral growth at different time points allowed us to better analyse the $30^{\circ} \mathrm{C}$ effect. This temperature was permissive for growth of the It/351/Sb strain, but this virus was less stable at this temperature, decreasing quickly in titre after the peak concentration of virus was reached.

Alterations observed in uninfected cells at 10 and $15^{\circ} \mathrm{C}$ indicate that these temperatures are in general unsuitable for the SSN-1 cell line. Despite suboptimal temperatures, the increase in virus titres shows that $15^{\circ} \mathrm{C}$ can be a permissive temperature for the It/351/Sb strain. This result could explain the evolution of some outbreaks observed at 14 to $15^{\circ} \mathrm{C}$ in the Mediterranean Sea. On the contrary we did not observe any viral growth at $10^{\circ} \mathrm{C}$, but cell death could interfere with virus replication, so we could not exclude the possibility that the It/351/Sb strain would be able to grow at this temperature.

Our study on the temperature growth range of the It/351/Sb strain provides evidence for variability between different strains of betanodaviruses that belong to the same genotype. Further, these in vitro effects of temperature on virus replication may have important counterparts for the in vivo growth of the virus and disease severity.

The mechanisms underlying the effects of temperature on in vitro and in vivo virus growth are necessary areas for future research on the betanodaviruses. Particularly, comparing other strains from different fish could elucidate if any correlation between host species and temperature behaviour exists.

\section{LITERATURE CITED}

Aranguren R, Tafalla C, Novoa B, Figueras A (2002) Nodavirus replication in a turbot cell line. J Fish Dis 25:361-366

Ball LA, Hendry DA, Johnson JE, Ruechert RR, Scotti PJ (2000) Family Nodaviridae. In: Van Regenmortel MHV, Fauquet CM, Bishop DHZ, Cartens EB and 7 others (eds) Virus taxonomy. Seventh Report of the International Committee on taxonomy of viruses. Academic Press, New York, p 747-755

Chi SC, Lin SC, Su HM, Hu WW (1999) Temperature effect on nervous necrosis virus infection in grouper cell line and in grouper larvae. Virus Res 63:107-114

Editorial responsibility: Jo-Ann Leong,

Kaneohe, Hawaii, USA
Chomczynsk P, Sacchi N (1987) Single-step method of RNA isolation by acid guanidiniumthiocyanate-phenol-chloroform extraction. Anal Biochem 162:156-159

Ciulli S, Ostanello F, Battilani M, Prosperi S, Hedrick RP (2004) Temperature effect on Betanodavirus infection in SSN-1 cell line. Vet Res Commun 28(Suppl 1):283-286

Curtis PA, Drawbridge M, Iwamoto T, Nakai T, Hedrick RP, Gendrom AP (2001) Nodavirus infection of juvenile white sea bass Atractoscion nobilis, cultured in southern California: first record of viral nervous necrosis (VNN) in North America. J Fish Dis 24:263-271

Frerichs GN, Rodger HD, Peric Z (1996) Cell culture isolation of piscine neuropathy nodavirus from juvenile sea bass, Dicentrarchus labrax. J Gen Virol 77:2067-2071

Fukuda Y, Nguyen HD, Furuhashi M, Nakai T (1996) Mass mortality of cultured seven band grouper, Epinephelus septemfasciatus, associated with viral nervous necrosis. Fish Pathol 31:165-170

Galeotti M, Beraldo P, Patarnello P, Sarli G, Volpatti D (1999) Encefalopatia-retinopatia virale (VER-VNN) in giovanili di branzino (D. labrax) in assenza di lesioni tipiche di vacuolizzazione cellulare. Boll Soc Ital Patol Ittica 27:45-56

Iwamoto T, Mori K, Arimoto M, Nakai T (1999) High permissivity of the fish cell line SSN-1 for piscine nodaviruses. Dis Aquat Org 39:37-47

Iwamoto T, Nakai T, Mori K, Arimoto M, Furusawa I (2000) Cloning of the fish cell line SSN-1 for piscine nodaviruses. Dis Aquat Org 43:81-89

Lai YS, Murali S, Chiu HC, Ju HY, Lin YS, Chen SC, Guo IC, Fang K, Chang CY (2001) Propagation of yellow grouper nervous necrosis virus (YGNNV) in a new nodavirussusceptible cell line from yellow grouper, Epinephelus awoara (Temminck \& Schlegel), brain tissue. J Fish Dis 24:299-309

Le Breton A, Grisez L, Sweetman J, Ollevier F (1997) Viral nervous necrosis (VNN) associated with mass mortalities in cage-reared sea bass, Dicentratchus labrax (L.). J Fish Dis 20:145-151

Mizumoto H, Hikichi Y, Okunot T (2002) The 3'-untranslated region of RNA1 as a primary determinant of temperature sensitivity of Red clover necrotic mosaic virus Canadian strain. Virology 293:320-327

Munday BL, Kwang J, Moody N (2002) Betanodavirus infections of teleost fish: a review. J Fish Dis 25:127-142

Nishizawa T, Mori T, Nakai T, Furusawa I, Muroga K (1994) Polymerase chain reaction (PCR) amplification of RNA of striped jack nervous necrosis virus (SJNNV). Dis Aquat Org 18:103-107

Nishizawa T, Furuhashi M, Nagai T, Nakai T, Muroga K, (1997) Genomic classification of fish nodaviruses by phylogenetic analysis of the coat protein gene. Appl Environ Microbiol 63:1633-1636

Reed LJ, Muench H (1938) A simple method of estimating fifty per cent end-points. Am J Hyg 27:493-497

Shuichi O, Miyanishi M, Shirako Y (2003) The optimal temperature for RNA replication in cells infected by Soilborne wheat mosaic virus is $17^{\circ} \mathrm{C}$. J Gen Virol 84:995-1000

Tanaka S, Aoki H, Nakai T (1998) Pathogenicity of the nodavirus detected from diseased seven band grouper Epinephelus semptemfasciatus. Fish Pathol 33:31-36

Thompson JD, Higgins DG, Gibson TJ (1994) CLUSTAL W: improving the sensivity of progressive multiple alignment through sequence weighting, position-specific gap penalties and weight matrix choice. Nucleic Acids Res 22:4673-4680

Submitted: September 6, 2004; Accepted: October 27, 2005

Proofs received from author(s):January 20, 2006 